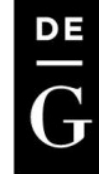

DOI 10.2478/pesd-2014-0035

PESD, VOL. 8, no. 1,2014

\title{
THE IMPACT OF WEATHER AND CLIMATE RISKS ON CEREAL CROPS PRODUCTIVITY
}

\author{
Maria Nedealcov ${ }^{1}$, \\ Key words: climate risks, impact, productivity, cereal crops, weather.
}

\begin{abstract}
Increase the intensity and frequency of the weather and climate risks contribute to compromised harvests in recent decades. Analysis of financial losses indicates that in 2007 and 2012 substantial values were reached. In this context it is important to know their regional peculiarities of manifestation both in present and in the years to come. The results shows that pronounced manifestation of the weather and climate risks in recent years (2000-2013) contributed to the decline of winter wheat harvest of $2 q$ / ha compared with the harvest that is expected in the 2020s calculated according to the most drastic SRES B2A scenario. The results are extremely necessary to take adaptation measures to new climatic conditions and to food security for the future in the Republic of Moldova.
\end{abstract}

\section{Introduction}

The agriculture, the main branch of national economy, as in the European Union countries, faces some serious environmental challenges, the main of which are: deficit and competition for water resources, climate change and lack of adaptation strategies to these changes, at local and regional level. According to (IPCC, 2013), climate change is already happening and will continue to happen; even if greenhouse gas emissions will be reduced. The impact of climate change on agricultural sector shows that these effects vary between different regions at different scales. Overall, changes in agricultural production highlight the vulnerability of food security (Tachie-Obengi E et all., 2010), showing a reasonable concern that climate change and associated climate risks represent threat of the poverty to sustainable development; also it refers also to our country (Nedealcov M., 2014).

1 Institute of Ecology and Geography of the Academy of Sciences of Moldova, marianedealcov@yahoo.com 
In the Republic of Moldova, more of the national agricultural production consists of cereal and industrial crops and the weather and climate risks remain to be ones of the most important reasons that affect agriculture.

\section{Investigation materials and methods}

Harvest formation is a very complicated process largely determined by the crop biology and agro-meteorological conditions of the territory. In natural conditions with unstable moisture regime crops not fully realized their biological potential, according to the results previously obtained. Deviation from the optimal weather conditions causes decrease or total loss of crop productivity. This statement highlights the productivity modification from year to year. Overlapping of crop productivity, evolution of the multiannual thermal and precipitation regimes reveals influence of agrometeorological factors on the crop formation. In this context, it is important correlation of climatic factors with crop productivity in order to highlight their role in the production process.

In estimating the role of meteorological factors in the formation of productive process, in accordance with well known methods in the field of Agrometeorology (Pasov V., 1973), the harvest $\left(Y_{i}\right)$ of agricultural crops is considered as the sum of two components. This can be explained by the following expression:

$$
Y_{i}=Y_{i}^{(T)}+\Delta Y_{i}^{(T)},
$$

where $Y_{i}^{(T)}$ is shown as the average dynamic, determined by the tempo of agricultural development and climatic conditions close to multiannual average, and deviation from it $-\Delta Y_{i}^{(T)}$ is explained by favourable or unfavourable weather conditions, expressed as positive or negative anomalies in the harvest. Scenarios.

Simulations of grain crops harvest were conducted through SRES

Because the duration of dry days during May-August, directly influences attending the main crops ontological stages, Dry Periods Index (Izu) is proposed (Nedealcov M., 2012), which represents the ratio between their sums recorded in the concrete years by their multiannual data for the period indicated above. This index has the following expression:

$$
I z u=\frac{\sum z u_{(V-V I I I)}}{\bar{X} z u_{(V-V I I I)}},
$$

where $\Sigma z u_{(V-V I I I)}$ amount of dry days during the period (May-August) when the crops intensive growth and development is held, Izu (V-VIII) - annual average of days dry (May-August). 


\section{Analysis of the results}

Therefore, it was considered that in years with positive anomalies in productivity, agrometeorological factors were classed as favourable and vice versa negative anomalies in the productivity was determined by excess or deficiency of some of agrometeorological factors manifestation (unfavourable years).

a- winter wheat

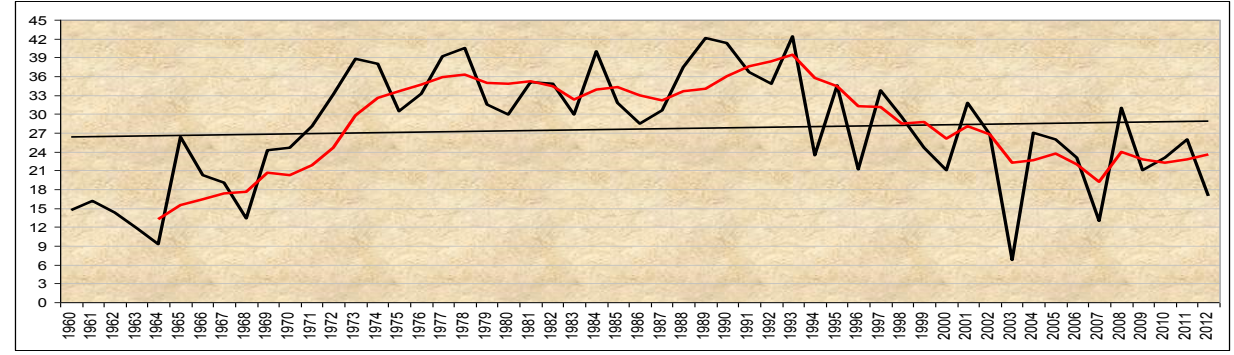

b-sunflowers

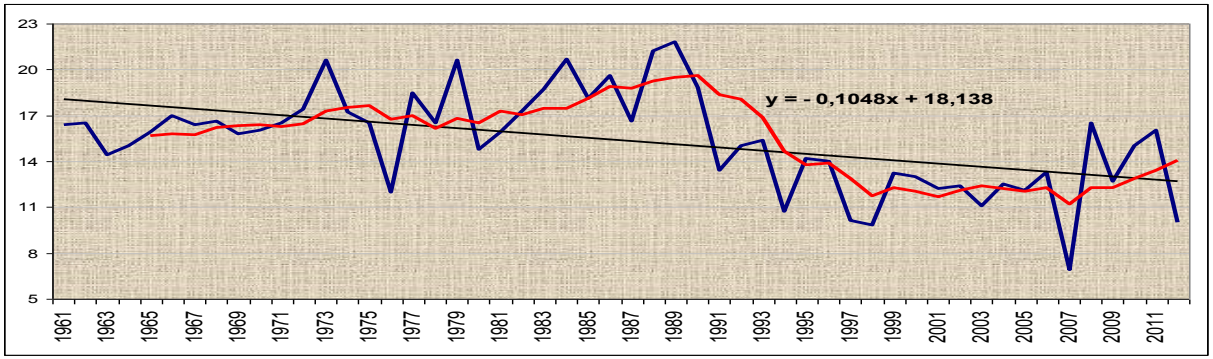

c- maize

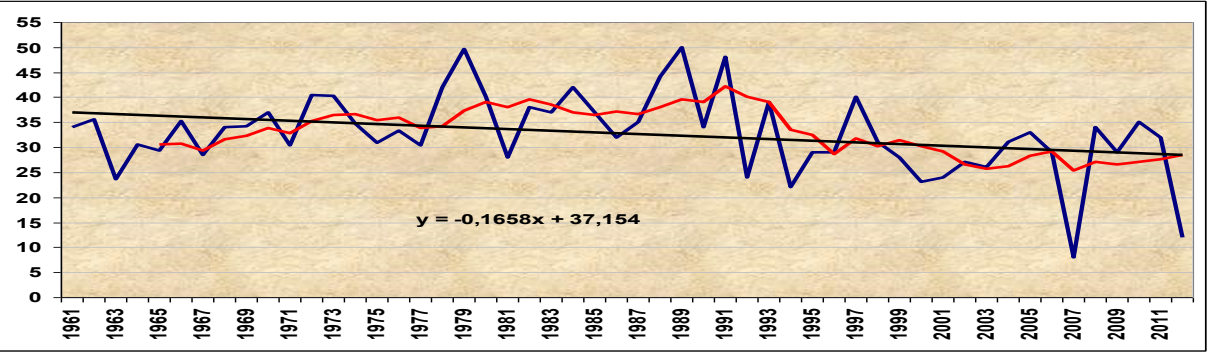

Figure 1. The modification tendency of the agricultural crops harvest taken in the study

Causes of harvest minor anomalies from the average dynamic are usually difficult to establish and it is considered that could be explained by the failure to comply of level of cultivation, pests influence, etc.

Removing them (conventionally) by trend component and estimation of positive and negative anomalies in the harvest crops during optimum or extreme 
years in terms of weather, was highlighted a close correlation relationship between environmental factors and the agricultural crops production.

Thus, it was found that the combined risks from 2007 and 2012 (high temperatures and lack of rainfall for a long time) contributed to the fact that corn and sunflower crops had the lowest values during the period of 1961- 2010 (Figure 1). For winter wheat we add and the year 2003, when due to the weather and climate risks during the winter also were established dry conditions in the generative phase (fig. 1).

Thus, the highly variable thermal and rainfall regime, especially in recent decades, has contributed to the emergence of climate change associated risks, especially droughts. According to the Department of Emergency Situations of the Republic of Moldova, among climate risks that have manifested in recent decades (1998-2013) in three years droughts contributed to the economic losses. Thus, the drought of 2002 damaged the country of about 2126.3 lei, the drought of 2007 caused material losses of 1002090.8 lei but material damages in 2012 were the most significant, and amounted 1,252,076.9 lei (fig. 2).

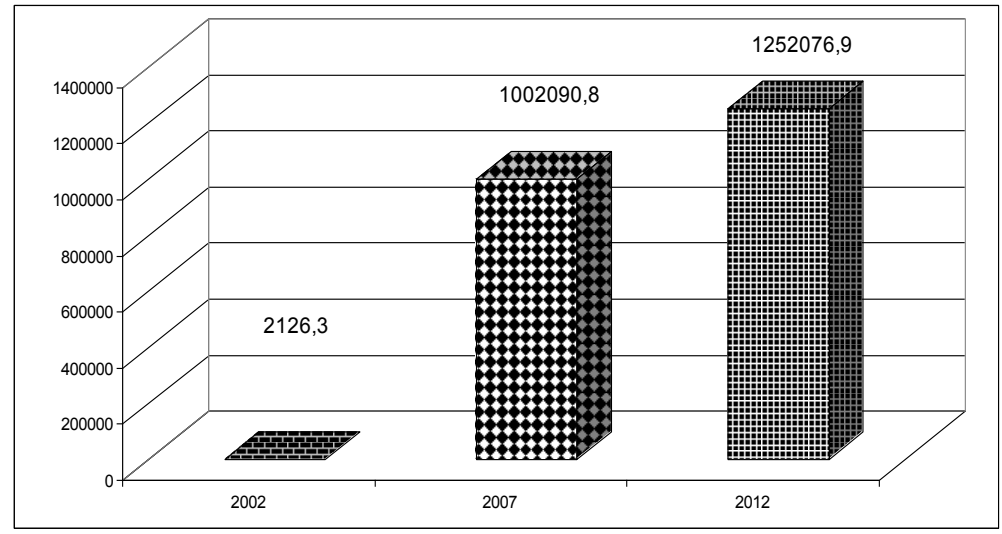

Figure 2. Material losses recorded after the worst drought conditions manifestation during the years 1998-2013

In the $\mathrm{XXI}^{\text {st }}$ century, the highest share of total material loss from the total weathercharacter risks over the Republic of Moldova, are droughts of 2007 and 2012. The separate analysis of climate risk manifestation for these years reveals that in the above nominated, material losses are generated from the manifestation of three risk categories. 

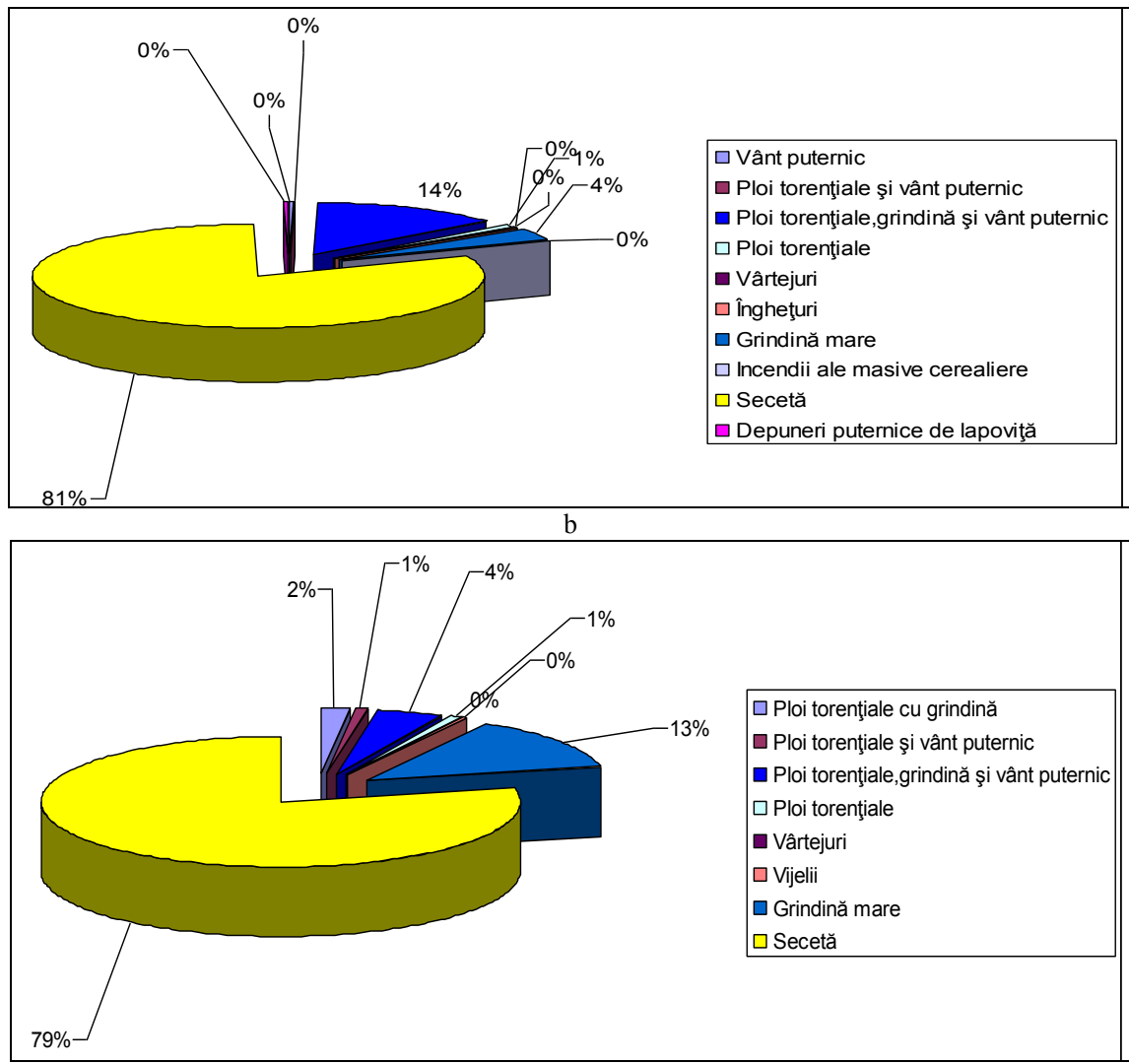

Figure 3.Share of material damages due to the drought of 2007 (a) and the drought of 2012 (b)

Thus, in 2007, in addition to material losses caused by drought (81\%), $15 \%$ of the losses were because of torrential rains accompanied with other risks such as strong winds or hail, and about $4 \%$ of damages due to large size hail manifestation, non combined with heavy rains (fig. 3a). In 2012, about $79 \%$ of the material damages are caused by the manifestation of drought. As in 2007, besides torrential rains that contributed to $8 \%$ of economic losses and about $13 \%$ of the economic damage has inflicted large hail (fig. 3b). 
Table1. Thermal extremes at different stages of climate evolution

\begin{tabular}{|c|c|c|c|c|}
\hline $\begin{array}{l}\text { The stages of climate } \\
\text { evolution }\end{array}$ & T min. abs. & T mas & abs. & At \\
\hline I 1960-2010 & -17.2 & 34.2 & & 51.4 \\
\hline II 1989-1999 & $\mid-16.8$ & 34.4 & 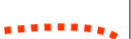 & 51.2 \\
\hline III $2000-2010$ & $\begin{array}{ll}-24,2 & 2006 \\
-21,8 & 2010\end{array}$ & $\begin{array}{l}36,3 \\
36,6 \\
36,6 \\
37,2 \\
37,5 \\
38,5 \\
39,5 \\
42.4 \\
\end{array}$ & $\begin{array}{c}2009 \\
2001 \\
2010 \\
2002 \\
2008 \\
2000 \\
2007 \\
2012\end{array}$ & 53.5 \\
\hline
\end{tabular}

Measurement of the extreme values modification (tab.1) in the Moldova's climate evolution indicates that absolute maximum of temperatures have a regular manifestation on the last period (2000-2010).

Increasing the climate continentally determine the estimation of saturation deficit (fig. 4), analysis which shows that it is constantly growing, since the 80 s of the XX century, more pronounced being observed during first decade of the XXI century (in the central and the southern part of the country) that denotes the intensification of the aridity processes in the Republic of Moldova.

Correlation of annual values of saturation deficit with that of the number of dry days indicates the close relationship the correlation between these two parameters $(0.8)$ throughout the country.

The estimation of saturation deficit $(\mathrm{mb})$ duration, concomitant evolution with that of the dry days' number indicates the increase values of these two climatic components since the 80 s of the XX century, and by end of the first decade of the XXI century records the essential practical values throughout the country (fig.4).

In parallel with the evaluation of spatio-temporal saturation deficit in the study were studied and the number of dry days during the active growing season for the months of May to August- the critical period, in terms of aridity and dryness for the growth and development of many crops groups. We mention that "dry days" are considered to be those days when temperatures are high (air $\mathrm{T}>25^{\circ} \mathrm{C}$ ) and low relative air humidity $(\mathrm{Ur}<30 \%)$ being considered as days with negative over of ontogenesis phases evolution. 
Evolutia deficitului de saturatie si a zlelor uscate (Briceni)

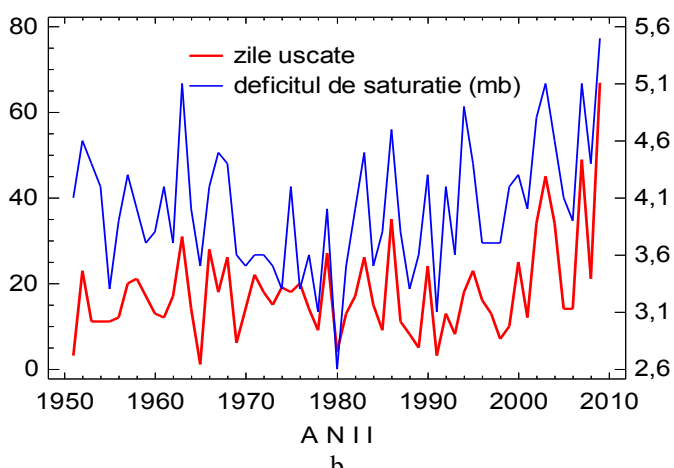

Evolutia deficitului de saturatie si a zilelor uscate (Chisinau)

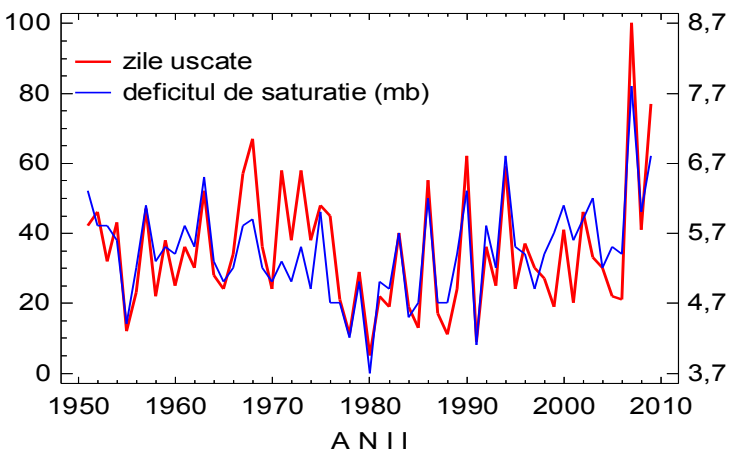

Evolutia deficitului de saturatie si a zilelor uscate (Cahul)

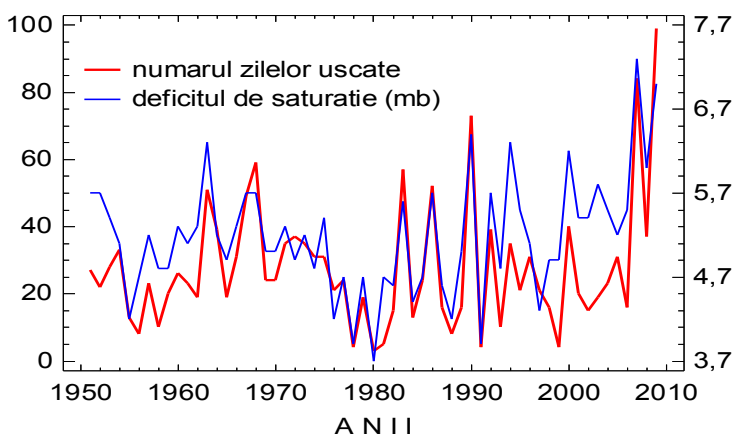

Figure 4. Evolution of saturation deficit (mb) and dry days over the Republic of Moldova (a-Briceni, b-Chisinau, c-Cahul) 
Because the duration of dry days during May-August, directly influences attending the main crops ontological stages, Dry Periods Index (Izu) is proposed, which represents the ratio between their sums recorded in the concrete years by their multiannual data for the period indicated above.

Table 2 Dry Periods Index Ratings (Izu) by M.Nedealcov

\begin{tabular}{|c|c|}
\hline Values Izu & Ratings $\mathbf{I} \boldsymbol{z} \boldsymbol{u}$ \\
\hline $\mathbf{0 , 1 - 1 , 0}$ & Normal period \\
\hline $\mathbf{1 , 1 - 2 , 0}$ & Moderate dry period \\
\hline $\mathbf{2 , 1 - 3 , 0}$ & Significant dry period \\
\hline $\mathbf{3 , 1 - 4 , 0}$ & Dangerous dry period \\
\hline$>\mathbf{4 , 1}$ & Exceptional dry period \\
\hline
\end{tabular}

Izu Ratings allow highlighting periods of aridity of dry days. So if Izu values $=2.1$ the sum of dry days double exceeds their annual average, by setting up a significant dry period (table 2).

Izu dynamic analysis demonstrates that in recent years it exceeds the limit of very dry periods and in the South of the country even, the limits of dangerous dry periods (fig.5).

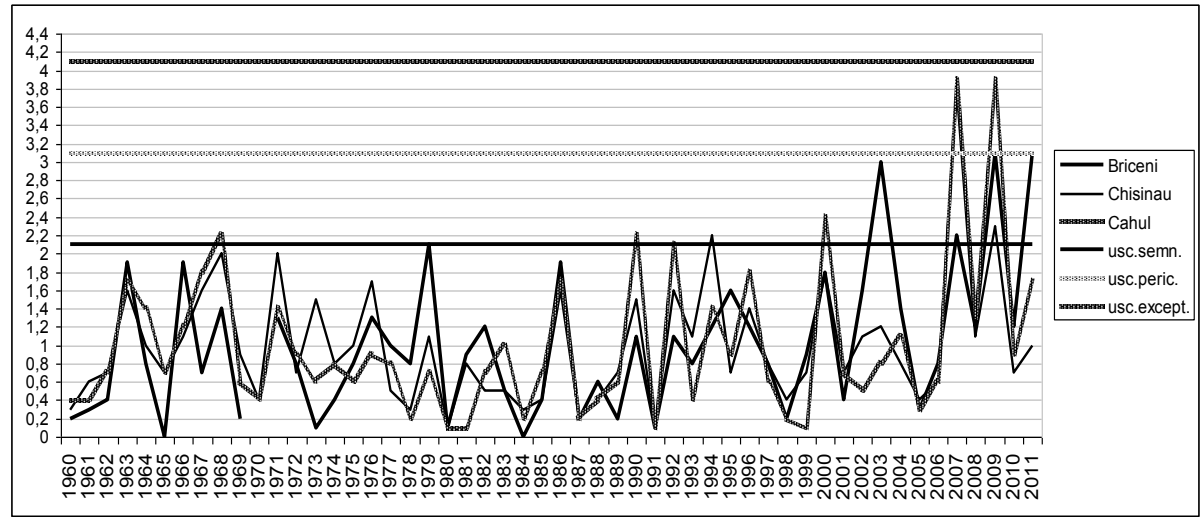

Figure 5. Temporal analysis of Izu

Izu cartographic modelling, for example in 2007, indicates that only in the north, in the months of May to August were established significant dry conditions (fig.6). 


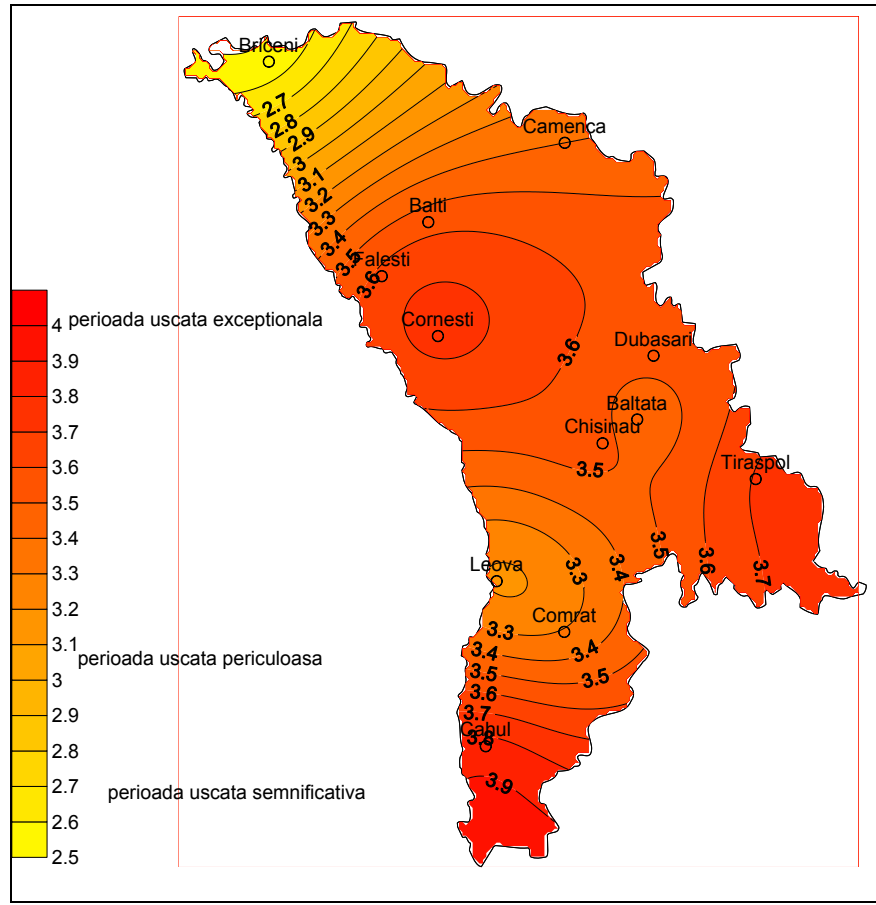

Figure 6. Cartographic Modelling of Dry Periods Index (Izu) in 2007

So, the impact of climate change is a major problem at present and it is a global issue, while conducting the prognostic character estimation could prepare mankind in carrying out adaptation measures and food security. Recent researches at the section climate change impacts on cultivation of certain crop groups reveal that these occur more rapidly than previously was anticipated. Crops harvest, according to these results, it is directly influenced by many aspects of climate change, resulting predominantly from: average temperature increase, significant variability in rainfall regime, increasing of $\mathrm{CO} 2$ atmospheric concentrations, the variability of extreme events associated with climate change. Increasing average, maximum and minimum temperatures are expected for countries with unstable humidity regime, which includes and the Republic of Moldova, a fact confirmed by previously researches. Is projected that in such regions, where water availability is reduced, to a warming of $2 \mathrm{C}$ in this century (Parry M., et all, 2004), some of the agricultural land will become unsuitable for crops grown. This will be largely due to increased evapotranspiration and decrease of soil moisture levels, leading itself to crop yield reduction. We note in this context, that the magnitude of these 
decreases, unfortunately, is still unknown, but some analysts suggest that they could be quite severe.

Therefore, changes in temperature and precipitation associated with the permanent $\mathrm{CO} 2$ emissions will bring changes to agricultural land suitability for maize development. According to the IPCC Special Report on associated emissions (SRES, 2000) and climate models designed to increase of global temperature (Quirogaa S., et all, 2007), some simulations of corn and wheat with reference to the Republic of Moldova.

According to these estimates, in the next years (2020), a drastic decrease in the yield of maize and winter wheat is expected - according to scenario SRES B2A (tab.3, tab.4), and by the 2020, corn yield will be about $25 \%$ less than the yield calculated for the period of 1970 to 2000 - period taken as the reference in projections calculations (http://sedac.ciesin.columbia.edu/data/collection/cropclimate/maps/gallery). Thus, in value expression of the real yields, if the annual average during the period 1970-2000 constitutes to the winter wheat $32.9 \mathrm{q} / \mathrm{ha}$ throughout the country, according to the majority SRES scenarios for 2020 (A1F SRES, SRES A2B, SRES B1A, SRES A2A, B2B), the autumn wheat harvest will decrease by $2.5 \mathrm{q} / \mathrm{ha}$. According to the less drastic scenario, for the same period, autumn wheat harvest over the Republic of Moldova will decrease by $1.3 \mathrm{q} / \mathrm{ha}$, and in the scenario SRES B2A - by 2020, the harvest may decrease by $8.2 \mathrm{q} /$ ha. Unfortunately, we find, however, that the autumn wheat yield calculated for the period 2000-2012 already is $22.7 \mathrm{q} /$ ha thus by $2 \mathrm{q} /$ ha less than the yield calculated with the most drastic scenario SRES B2A, which reveals that in the 2020 within the limits of Republic of Moldova could be yield of $24.7 \mathrm{q} / \mathrm{ha}$.

Likewise, in the case corn harvest, that calculated for the whole country already calculated for the period $2000-2012$ is $26.4 \mathrm{q} /$ ha, thus $0.2 \mathrm{q} /$ ha less than the yield calculated for the most drastic scenario (SRES B2A) which show that in value expression corn harvesting could be $26.6 \mathrm{q} /$ ha by the $2020 \mathrm{~s}$. We note that the average yield of maize calculated for the entire period taken in the study (19602012 ) is $32.8 \mathrm{q} / \mathrm{ha}$, in recent years, however, (2000-2012) it has decreased by 6.4 q / ha.

In the case of winter wheat yield changes design at regional level for the period 2080, according to scenario SRES A2A even have a positive prognostic yield by $1 \%$ from the annual average. More drastically, SRES B1A Scenario projects namely a decrease of $-30 \ldots-20 \%$ from the annual average. In the case A1F SRES, SRES A2B, SRES A2C - the autumn wheat yield will decrease by $-5 \ldots$ $-3 \%$, and in the case SRES B2A and B2B - it expected to decline to $-10 \ldots-5 \%$.

Thus, the real value expression yields, if the annual average during the period 1970-2000 throughout the country is $32.9 \mathrm{q} /$ ha, According to the majority SRES scenarios for 2020 (A1F SRES, SRES A2B, SRES B1A, SRES A2A, B2B), the 
autumn wheat yield will decrease by $25 \mathrm{q} / \mathrm{ha}$. According to the less drastic scenario, for the same period, autumn wheat harvest in the Republic will decrease by $1.3 \mathrm{q} / \mathrm{ha}$, and in the scenario SRES B2A - by 2020, the harvest may decrease by $8.2 \mathrm{q} / \mathrm{ha}$.

Table 3.The simulation of maize harvest for the years ahead

\begin{tabular}{|c|c|c|c|c|}
\hline & & \multicolumn{3}{|c|}{ Intervalul de timp } \\
\hline & $\begin{array}{l}\text { Scenariile } \\
\text { propuse }\end{array}$ & 2020 & 2050 & 2080 \\
\hline 1. & SRES $\mathrm{A}_{1} \mathrm{~F}$ & $-10 \ldots-5$ & $-30 \ldots-20$ & $-30 \ldots-20$ \\
\hline 2. & SRES $\mathrm{A}_{2} \mathrm{~B}$ & $-10 \ldots-5$ & $-30 \ldots-20$ & $-30 \ldots-20$ \\
\hline 3. & SRES B $_{1} \mathrm{~A}$ & $-10 \ldots-5$ & $-30 \ldots-20$ & $-30 \ldots-20$ \\
\hline 4. & SRES $\mathrm{A}_{2} \mathrm{~A}$ & $-10 \ldots-5$ & $-30 \ldots-20$ & $-30 \ldots-20$ \\
\hline 5. & SRES $\mathrm{A}_{2} \mathrm{C}$ & $-10 \ldots-5$ & $-30 \ldots-20$ & $-30 \ldots-20$ \\
\hline 6. & $\mathrm{SRES} \mathrm{B}_{2} \mathrm{~A}$ & $-30 \ldots-20$ & $-30 \ldots-20$ & $-30 \ldots-20$ \\
\hline 7. & SRES B ${ }_{2} \mathrm{~B}$ & $-10 \ldots-5$ & $-30 \ldots-20$ & $-30 \ldots-20$ \\
\hline
\end{tabular}

Table 4.The simulation of winter wheat harvest for the years ahead

\begin{tabular}{|c|c|c|c|c|}
\hline & & \multicolumn{3}{|c|}{ Intervalul de timp } \\
\hline & Scenariile propuse & $\mathbf{2 0 2 0}$ & $\mathbf{2 0 5 0}$ & $\mathbf{2 0 8 0}$ \\
\hline 1. & SRES $\mathrm{A}_{1} \mathrm{~F}$ & $-10 \ldots-5$ & $-10 \ldots-5$ & $-5 \ldots-3$ \\
\hline 2. & SRES $_{2} \mathrm{~B}$ & $-10 \ldots-5$ & $-10 \ldots-5$ & $-5 \ldots-3$ \\
\hline 3. & SRES $_{1} \mathrm{~A}$ & $-10 \ldots-5$ & $-10 \ldots-5$ & $-30 \ldots-20$ \\
\hline 4. & SRES $_{2} \mathrm{~A}$ & $-10 \ldots-5$ & $-10 \ldots-5$ & $-1 \ldots+1$ \\
\hline 5. & SRES $_{2} \mathrm{C}$ & $-5 \ldots-3$ & $-10 \ldots-5$ & $-5 \ldots-3$ \\
\hline 6. & SRES $_{2} \mathrm{~A}$ & $-30 \ldots-20$ & $-10 \ldots-5$ & $-10 \ldots-5$ \\
\hline 7. & SRES $_{2} \mathrm{~B}$ & $-10 \ldots-5$ & $-30 \ldots-20$ & $-10 \ldots-5$ \\
\hline
\end{tabular}

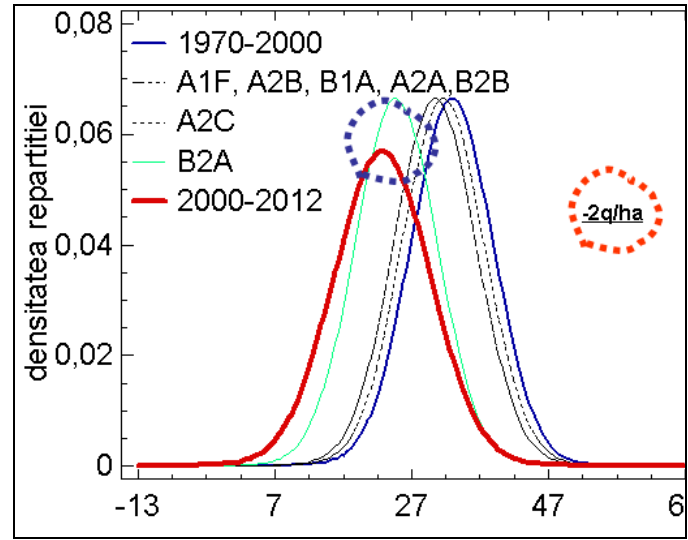

Figure 7 . The analysis of winter wheat harvest distribution density 
Unfortunately, we find, however, that the autumn wheat yield calculated for the period 2000-2012 already is $22.7 \mathrm{q} /$ ha thus by $2 \mathrm{q} /$ ha less than the yield calculated with the most drastic scenario SRES B2A, which reveals that in the 2020 Moldova harvest limits it would be $24.7 \mathrm{q} /$ ha.

In conclusion we note that regional climate change represents one of the major threats to sustainable development and is one of the biggest environmental problems, with negative consequences for the national economy.

\section{Conclusions}

Besides the fact that currently is preparing the third National Report on Climate Changes, at the national level, unfortunately there are no lows that would take into account the priority of this environmental issue; we do not have the strategy of adaptation to climate change and realisation the 10-year strategic plan and framework to enhance the implementation of the Desrtification Convention in national level.

\begin{tabular}{|c|c|}
\hline \multicolumn{2}{|c|}{ SWOT analysis } \\
\hline Strengths & Opportunities \\
\hline $\begin{array}{l}\text { Shows that the strength is the fact that the } \\
\text { country's produc-tion potential climate } \\
\text { offers high value crops, especially fruits } \\
\text { and vegetables, which present an important } \\
\text { thing for increasing farmers' income - } \\
\text { agriculture, the basic industry of the } \\
\text { national economy. }\end{array}$ & $\begin{array}{l}\text { The main opportunities noted that now, } \\
\text { of the agricultural sector is a major } \\
\text { potential but largely untapped and } \\
\text { unused. Efforts to increase the } \\
\text { competitiveness of Moldovan agricultu- } \\
\text { ral products, given the new climate } \\
\text { conditions will lead to a transformation } \\
\text { of Moldovan agriculture highly } \\
\text { productive and profitable business. }\end{array}$ \\
\hline Weaknesses & Threats \\
\hline $\begin{array}{l}\text { Weaknesses are conditioned by the fact that } \\
\text { the country is vulnerable to a number of } \\
\text { risks negative impacts on rural incomes, } \\
\text { including droughts, floods, hails, which in } \\
\text { the context of current climate change show } \\
\text { a higher intensity and frequency. } \\
\text { Yield per hectare is low compared to other } \\
\text { countries in the region varies greatly every } \\
\text { year, which indicates lack of mechanisms } \\
\text { for adaptation and mitigation of climate } \\
\text { change and risks in agriculture. }\end{array}$ & $\begin{array}{l}\text { And threats are: } \\
\text { Possible natural disasters such as drought, } \\
\text { floods, hail, etc. } \\
\text { Lack of intersectorial national strategy to } \\
\text { reduce the impact of climate change and } \\
\text { risks. } \\
\text { Agricultural practices that do not take into } \\
\text { account the possible negative effects of } \\
\text { climate change on soil, environment and } \\
\text { biodiversity is a serious threat to } \\
\text { sustainable development. }\end{array}$ \\
\hline
\end{tabular}


SWOT analysis shows that the strength is the fact that the country's production potential climate offers high value crops, especially fruits and vegetables, which present an important thing for increasing farmers' income - agriculture, the basic industry of the national economy.

Weaknesses are conditioned by the fact that the country is vulnerable to a number of risks negative impacts on rural incomes, including droughts, heavy rains, hail, frost, floods, which in the context of current climate change show a higher intensity and frequency. Yield per hectare is low compared to other countries in the region varies greatly every year, which indicates lack of mechanisms for adaptation and mitigation of climate change and risks in agriculture. The main opportunities noted that now, of the agricultural sector is a major potential but largely untapped and unused. Efforts to increase the competitiveness of Moldovan agricultural products, given the new climate conditions will lead to a transformation of Moldovan agriculture highly productive and profitable business.

And threats are: Possible natural disasters such as drought, floods, hail, etc. Lack of a intersectoral national strategy in order to reduce the impact of climate change and risks. Agricultural practices that do not take into account the possible negative effects of climate change on soil, environment and biodiversity is a serious threat to sustainable development.

\section{References}

Nedealcov M., (2014) Impactul schimbărilor de climă asupra productivitătiii unor culturi agricole. Akademos.Chişinău, Nr.2(33), 62-65.

Nedealcov, M. Resursele agroclimatice în contextul schimbărilor de climă Tipografia"Alina Scorohodova" 2012, Chișinău, 306 p.

Parry M.,*, Rosenzweigb C., Iglesiasc A., Livermored M., Fischere G. (2004) Effects of climate change on global food production under SRES emissions and socioeconomic scenarios Global Environmental Change 14, 53-67.

Tachie-Obengi E., Gyasi E., Adiku S., Abekoe M. and Ziervogel G. (2010) Farmers' adaptation measures in scenarios of climate change for maize production in semi-arid zones of Ghana 2nd International Conference: Climate, Sustainability and Development in Semi-arid Regions August 16 - 20, 2010, Fortaleza - Ceará, Brazil.

Quirogaa S., Iglesias A. (2007) Eсопотна Agraria y Recursos Naturales. Projections of economic impacts of climate change in agriculture in Europe ISSN: 1578-0732. Vol. 7, 14. (2007). pp. 65-82.

Пасов В.М. (1973) Климатическая изменчивость урожаев озимой пшеницы. //Метеорология и гидрология.-1973.- Nr. 2.- С. 94-103.

http://sedac.ciesin.columbia.edu/data/collection/crop-climate/maps/gallery 